\title{
A Process Model for the Production of Hydrogen Using High Temperature Electrolysis
}

\section{International Conference on Nuclear Engineering (ICONE-14)}

\author{
Michael G. McKellar \\ Edwin A. Harvego \\ Matt Richards \\ Arkal Shenoy
}

July 2006

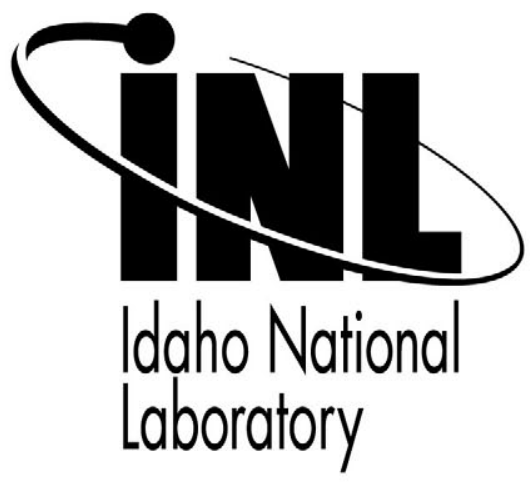

This is a preprint of a paper intended for publication in a journal or proceedings. Since changes may not be made before publication, this preprint should not be cited or reproduced without permission of the author. This document was prepared as an account of work sponsored by an agency of the United States Government. Neither the United States Government nor any agency thereof, or any of their employees, makes any warranty, expressed or implied, or assumes any legal liability or responsibility for any third party's use, or the results of such use, of any information, apparatus, product or process disclosed in this report, or represents that its use by such third party would not infringe privately owned rights. The views expressed in this paper are not necessarily those of the United States Government or the sponsoring agency. 


\title{
ICONE14-89694
}

\section{A PROCESS MODEL FOR THE PRODUCTION OF HYDROGEN USING HIGH TEMPERATURE ELECTROLYSIS}

\author{
Michael G. McKellar, Edwin A. Harvego \\ Idaho National Laboratory \\ Matt Richards, Arkal Shenoy \\ General Atomics
}

\begin{abstract}
High temperature electrolysis (HTE) involves the splitting of steam into hydrogen and oxygen at high temperatures. The primary advantage of HTE over conventional low temperature electrolysis is that considerably higher hydrogen production efficiencies can be achieved. Performing the electrolysis process at high temperatures results in more favorable thermodynamics for electrolysis, more efficient production of electricity, and allows direct use of process heat to generate steam. This paper presents the results of process analyses performed to evaluate the hydrogen production efficiencies of an HTE plant coupled to a $600 \mathrm{MWt}$ Modular Helium Reactor (MHR) that supplies both the electricity and process heat needed to drive the process. The MHR operates with a coolant outlet temperature of $950 \mathrm{C}$. Approximately $87 \%$ of the hightemperature heat is used to generate electricity at high efficiency using a direct, Brayton-cycle power conversion system. The remaining high-temperature heat is used to generate a superheated steam / hydrogen mixture that is supplied to the electrolyzers. The analyses were performed using the HYSYS process modeling software. The model used to perform the analyses consisted of three loops; a primary high temperature helium loop, a secondary helium loop and the HTE process loop. The detailed model included realistic representations of all major components in the system, including pumps, compressors, heat exchange equipment, and the electrolysis stack. The design of the hydrogen production process loop also included a steam-sweep gas system to remove oxygen from the electrolysis stack so that it can be recovered and used for other applications. Results of the process analyses showed that hydrogen production efficiencies in the range of $45 \%$ to $50 \%$ are achievable with this system.
\end{abstract}

\section{INTRODUCTION}

Because of its ability to produce high-temperature helium, the MHR is well suited for a number of nuclear process-heat applications, including hydrogen production. Two hydrogenproduction technologies have emerged as leading candidates for coupling to the MHR: thermochemical water splitting using the sulfur-iodine (SI) process and high-temperature electrolysis (HTE). In this paper, we discuss a conceptual design developed for coupling the MHR to the HTE process. $[1,2,3,4]$.

\section{MODEL DESCRIPTION}

A process model of the high temperature electrolysis (HTE) plant combined with a high temperature helium reactor was completed using Hyprotech's HYSYS process modeling software. The model, shown in Figure 1, consists of three loops: a primary high temperature helium loop, a secondary helium loop and the HTE process loop.

Helium in the primary loop passes through the reactor, providing cooling for the high temperature reactor fuel by removing $600 \mathrm{MW}$ of thermal power from the reactor core. The high temperature helium leaving the reactor is then split into two streams, with a small fraction of the flow $(13 \%)$ delivered to an intermediate heat exchanger to provide heat to the HTE process streams, and the majority of the flow passing through a Brayton-cycle gas turbine producing electrical power. After passing through the gas turbine, the major flow stream is further cooled through a recuperator and an ambient precooler heat exchanger. The cool gas is compressed to an intermediate pressure via the low-pressure compressor. The heat of compression is removed using an intercooler heat exchanger. The gas is further compressed to full pressure as it passes through the high-pressure compressor. The gas is then heated by passing through the recuperator. The resulting stream is mixed with the exit stream of the intermediate heat exchanger before entering the reactor. The second stream ( $13 \%$ of the total primary system flow) is passed through an intermediate heat exchanger where the heat is transferred to the secondary helium loop, after which the stream is then slightly compressed using the primary side circulator. Tables $1 \& 2$ list the properties found in the primary loop.

The secondary helium loop consists of the other side of the intermediate heat exchanger and three additional process heat exchangers. Two of the heat exchangers provide heat to the hydrogen/water side of the HTE process and the remaining heat exchanger heats the steam used to sweep the

This material is declared a work of the U.S. Government and is not subject to copyright protection in the United States. Approved for public release; distribution is unlimited. 
oxygen from the electrolysis process. Tables $3 \& 4$ show the conditions calculated for this loop.

\begin{tabular}{|c|c|c|c|}
\hline Stream & $\begin{array}{c}\text { Temperature } \\
\left({ }^{\circ} \mathrm{C}\right)\end{array}$ & $\begin{array}{c}\text { Pressure } \\
(\mathrm{MPa})\end{array}$ & $\begin{array}{c}\text { Flow } \\
(\mathrm{kg} / \mathrm{s})\end{array}$ \\
\hline 11 - Reactor Inlet & 590 & 7.07 & 321 \\
\hline 1 - Reactor Outlet & 950 & 7.00 & 321 \\
\hline 2 - Turbine Inlet & 950 & 7.00 & 279 \\
\hline 5 - Turbine Outlet & 600 & 2.80 & 279 \\
\hline 3 - Precooler Inlet & 129 & 2.77 & 279 \\
\hline 4 - Precooler Outlet & 26 & 2.74 & 279 \\
\hline $\begin{array}{c}\text { 6 - Low Pressure } \\
\text { Compressor Outlet }\end{array}$ & 93 & 4.31 & 279 \\
\hline $\begin{array}{c}\text { 9 - High Pressure } \\
\text { Compressor Inlet }\end{array}$ & 26 & 4.27 & 279 \\
\hline $\begin{array}{l}10 \text { - High Pressure } \\
\text { Compressor Outlet }\end{array}$ & 104 & 7.14 & 279 \\
\hline $\begin{array}{c}8 \text { - High Pressure } \\
\text { Recuperator Outlet }\end{array}$ & 575 & 7.07 & 279 \\
\hline $\begin{array}{c}7 \text { - Intermediate Heat } \\
\text { Exchanger Inlet }\end{array}$ & 950 & 7.00 & 42 \\
\hline $\begin{array}{l}\text { 13 - Intermediate Heat } \\
\text { Exchanger Outlet }\end{array}$ & 679 & 6.93 & 42 \\
\hline $\begin{array}{l}\text { 12 - Primary Side } \\
\text { Circulator Outlet }\end{array}$ & 689 & 7.07 & 42 \\
\hline
\end{tabular}

Table 1. Temperatures, pressures, and flows of primary loop

\begin{tabular}{|l|c|}
\hline \multicolumn{1}{|c|}{ Component } & Power or Heat Flow (kW) \\
\hline Reactor Heat & 600,000 \\
\hline Turbine Power & 510,215 \\
\hline High Pressure Compressor Power & 114,959 \\
\hline Low Pressure Compressor Power & 98,676 \\
\hline Primary Side Circulator Power & 2,224 \\
\hline Recuperator Duty & 683,261 \\
\hline Precooler Cooling & 149,424 \\
\hline Intercooler Cooling & 97,489 \\
\hline Intermediate Heat Exchanger Duty & 58,730 \\
\hline
\end{tabular}

Table 2. Power and heat flows of primary loop

\begin{tabular}{|l|c|c|c|}
\hline \multicolumn{1}{|c|}{ Stream } & $\begin{array}{c}\text { Temperature } \\
\left({ }^{\circ} \mathrm{C}\right)\end{array}$ & $\begin{array}{c}\text { Pressure } \\
(\mathrm{MPa})\end{array}$ & $\begin{array}{c}\text { Flow } \\
(\mathrm{kg} / \mathrm{s})\end{array}$ \\
\hline $\begin{array}{l}\text { 14 - Intermediate Heat } \\
\text { Exchanger Inlet }\end{array}$ & 292 & 6 & 18.1 \\
\hline $\begin{array}{l}\text { 15 - Intermediate Heat } \\
\text { Exchanger Outlet }\end{array}$ & 917 & 5.94 & 18.1 \\
\hline 22 - HX4 Outlet & 854 & 5.88 & 18.1 \\
\hline 27 - HX3 Outlet & 530 & 5.82 & 18.1 \\
\hline 23 - HX2 Outlet & 280 & 5.76 & 18.1 \\
\hline
\end{tabular}

Table 3. Temperatures, pressures, and flows of secondary helium loop

\begin{tabular}{|l|c|}
\hline \multicolumn{1}{|c|}{ Component } & $\begin{array}{c}\text { Power or Heat Flow } \\
(\mathrm{kW})\end{array}$ \\
\hline Secondary Side Circulator Power & 1,154 \\
\hline Intermediate Heat Exchanger Duty & 58,730 \\
\hline HX2 Duty & 23,473 \\
\hline HX3 Duty & 30,440 \\
\hline HX4 Duty & 5,971 \\
\hline
\end{tabular}

Table 4. Power and heat flow of secondary helium loop

The final loop is the HTE process loop which consists of the hydrogen-steam side and the steam sweep side. Make-up water is pumped to the electrolysis pressure in the liquid phase and is combined with the recycled water. The water is heated to a saturated state through heat exchanger HX1. The heat from heat exchanger HX2 boils off the remaining water after which recycled hydrogen is added to the stream. In this case study, the composition of the stream after the hydrogen addition is $10 \%$ hydrogen and $90 \%$ steam by mole basis. The hydrogen is added to the inlet stream in order to maintain reducing conditions at the steam/hydrogen electrodes of the electrolysis cells. Heat exchanger HX3 raises the temperature of the steam/hydrogen mixture to as close to the desired electrolysis temperature as possible using heat from the helium secondary side. A high temperature electrical heater (High Temperature Heater) is used to provide the additional heat needed for the electrolysis process. The hydrogen/steam stream leaving the electrolysis process is $90 \%$ hydrogen and $10 \%$ steam on a mole basis. The water from the hydrogen/steam leaving the electrolysis process is condensed using the heat exchanger HX1. The condensed water is recycled and the hydrogen stream is split into two streams. The first stream is the hydrogen product stream and the second stream is the recycled hydrogen added before the electrolysis process.

The sweep gas is created by pumping water to the electrolysis pressure. The water is boiled and superheated in the heat exchanger HX5 by the sweep steam and oxygen leaving the electrolysis process. The steam is further heated in heat exchanger HX4 to the electrolysis temperature using heat from the helium secondary loop. After the electrolysis process, the steam/oxygen stream composition is $50 \%$ steam and $50 \%$ oxygen on a mole basis. The steam/oxygen stream is cooled in heat exchanger HX5 to a saturated state. The water is removed at the High Pressure $\mathrm{H} 2 \mathrm{O} / \mathrm{O} 2$ Knockout Tank and then expanded through a turbine to atmospheric pressure. The stream is further cooled in the Low Pressure $\mathrm{H} 2 \mathrm{O} / \mathrm{O} 2$ Knockout Tank to the ambient temperature and the water is removed from the stream. See Tables 5 and 6 for the resulting conditions in this loop.

Since the electrolyzer is not a standard HYSYS component, a custom high-temperature electrolysis model was developed for inclusion in the overall system model. The electrolysis model, shown on the right side of Figure 1, is based on the first law of thermodynamics and the Nernst equation. Details of the model can be found in the papers by O'Brien, et. al. $[5,6,7]$ For this simulation, the electrolyzer cells have cell cross sectional areas of $225 \mathrm{~cm}^{2}$ and a current 
density of $0.25 \mathrm{~A} / \mathrm{cm}^{2}$ resulting in a total current of $56.25 \mathrm{~A}$. The electrolysis inlet temperature was set to $1100 \mathrm{~K}$. Four millions cells were used, requiring $292 \mathrm{MW}$ of electrolysis power to produce $2345 \mathrm{~g} / \mathrm{s}$ of hydrogen. The area specific resistance (ASR) of each cell is temperature averaged but based on a value specified at $1100 \mathrm{~K}$. For this model, the ASR at $1100 \mathrm{~K}$ was set at $1.25 \mathrm{ohms}^{*} \mathrm{~cm}^{2}$, resulting in a temperature averaged ASR of $1.132 \mathrm{ohm} * \mathrm{~cm}^{2}$. The model predicted the operating voltage as 1.3 volts per cell. The electrolysis process was operating slightly above thermal neutral which resulted in an electrolysis outlet temperature that was above the inlet temperature. At the thermal neutral voltage, the electrolysis exit temperature is the same as the inlet temperature. The thermal neutral voltage for this case is 1.286 volts per cell at a current level of 47.5 amperes; therefore the extra voltage and current provided heating to the products of the electrolysis process. This extra heat can be recovered by preheating the process or sweep streams.

\section{EFFICIENCY}

As discussed in the following section, overall hydrogen production efficiencies will be affected by the assumed performance of the heat exchangers used in the process. In this analysis each heat exchanger has an effectiveness of 0.95 or less. The effectiveness of a heat exchanger is defined as the ratio of the actual heat transfer to the maximum possible heat transfer. Pressure losses within each heat exchanger were set at $1 \%$ of the maximum pressure within each loop. Table 7 shows the effectiveness and minimum approach temperatures of each heat exchanger in the system.

The efficiency of the system is calculated in the following manner. The control volume for the efficiency calculation surrounds all three loops and the sweep gas. First the net power of the turbomachinery is found.

$$
\begin{aligned}
& \text { Net Power } \\
& { }_{\text {Turbomachinery }}=\sum \text { Power }_{\text {Turbines }} \\
& -\sum \text { Power }_{\text {Compressors }}-\sum \text { Power }_{\text {Pumps }}
\end{aligned}
$$

The net total of the electric power into the total system is also found. This total is the sum of the electrical power into the electrolysis process and the sweep gas heater.

$$
\text { Net Power } \text { Electrical }=\text { Power }_{\text {Electrolysis }}+\text { Power }_{\text {Sweep Heater }}
$$

Also the heating value power of the hydrogen product is calculated.

$$
\text { Power }_{\mathrm{H}_{2}}=\dot{\mathrm{m}}_{\mathrm{H}_{2} \text { Produced }} \mathrm{x} \text { Lower Heating Value } \mathrm{H}_{2}
$$

The efficiency is calculated as follows:

$$
\eta=\frac{\text { Net Power }_{\text {Turbomachinery }}+\text { Power }_{\mathrm{H}_{2}}-\text { Net Power }}{\text { Electrical }}
$$

The numerator is the net power produced and the denominator is the heat power into the system. The efficiency as shown in equation (4) can be also defined as the net power produced over the net power into the system.

\section{RESULTS}

Figures 2 through 7 are temperature vs. heat flow plots of the heat exchangers in the secondary loop and the electrolysis loop. Figure 2 show the profile in the heat exchanger HX1. The cold stream is the recycled water combined with the make-up water. HX1 heats this stream to a saturation state. The hot stream is the $90 \%$ hydrogen- $10 \%$ water stream. This stream is superheated as it enters the heat exchanger. As can be seen on the plot, the dew point of the stream is $147.7^{\circ} \mathrm{C}$ at which point the steam begins to condense. Most of the steam is condensed, but is temperature-limited by the temperature of the incoming water stream on the cold side. Figure 3 is the profile plot of heat exchanger HX2. The cold stream is the water stream from HX1. This stream is heated until the stream is slightly superheated to allow the addition of recycled cold hydrogen from the hydrogen product gas. The hot stream is the helium in the secondary loop. Figure 4 shows the temperature vs. heat flow plot of heat exchanger HX3. Although it would appear more heat could be transferred from the secondary helium loop to the steam/hydrogen stream, the heat duty of HX3 is limited due to the heat requirements of HX4 and HX5 to superheat the sweep water to electrolysis temperatures. If the duty of HX3 were to increase, the required duty of HX5 could not be achieved and an external heater would need to be added to heat the sweep gas. An additional external heater is needed to heat up the stream/hydrogen stream to the inlet electrolysis temperatures. Figure 5 shows the temperature/heat flow profile of HX4. The primary purpose of HX4 is to provide the remaining duty required to heat the sweep gas to the electrolysis inlet temperature. As can be seen in Figure 6, HX5 is limited by two phase regions on both sides of the heat exchanger. The cold stream is incoming water that is to be used as the sweep gas. HX5 provides the heat to superheat the water. The hot stream is the $50 \%$ oxygen $/ 50 \%$ steam stream coming from the electrolysis process. The steam in the hot stream begins to condense at $218.8^{\circ} \mathrm{C}$. The final plot is of the intermediate heat exchanger, see Figure 7. Both streams are helium, the hot stream is from the primary loop and the cold stream is from the secondary loop.

The high temperature reactor supplies both high temperature heat and electric power to the HTE process. The high temperature heat was used to heat the sweep gas to the electrolysis temperature. However, there was not quite enough high temperature heat to heat the process stream to 
the desired electrolysis temperature, due primarily to the $95 \%$ effectiveness constraint on the heat exchangers. However, the resistance heater (High Temperature Heater) provided the additional heat needed from electric power generated by the Brayton power cycle. When compared to a low temperature reactor, the high temperature reactor provides electricity at a higher thermal efficiency thereby increasing the overall hydrogen production efficiency.

For this system the calculated overall efficiency is $47.9 \%$. In a previous model, the heat exchangers were maximized for heat transfer but limited by a $5^{\circ} \mathrm{C}$ minimum approach temperature and the pressure drops were set at $20 \mathrm{kPa}$. In the previous model the overall efficiency was $51.3 \%$. Also in the previous model, there was sufficient heat to raise both the process and sweep streams to the desired electrolysis temperatures, thereby eliminating the High Temperature Heater. As can be seen, using more realistic heat exchanger design parameters decreases the overall efficiency of the system by about $3.4 \%$.

\section{CONCLUSIONS}

A process model of the Modular Helium Reactor combined with a high temperature electrolysis process has shown that efficiencies of nearly $50 \%$ can be achieved. In developing these models, realistic heat exchange effectiveness and pressure drops need to be considered to prevent over estimating the expected efficiencies.

\section{REFERENCES}

1. M. Richards and A. Shenoy, "Hydrogen Generation Using the Modular Helium Reactor," Proceedings of the $12^{\text {th }}$ International Conference on Nuclear Engineering, April 25-19, 2004, Arlington, Virginia, American Society of Mechanical Engineers (2004).

2. M. Richards, A. Shenoy, and K. Schultz, "MHRBased Hydrogen Production Systems," Proceedings of the 2004 International Congress on Advances in Nuclear Power Plants(ICAPP '04), June 13-17, Pittsburgh, PA, American Nuclear Society (2004).

3. M. Richards et. al., "Thermal Hydraulic Design of a Modular Helium Reactor Core Operating at $1000^{\circ} \mathrm{C}$.

4. L. C. Brown et. al., "High Efficiency Generation of Hydrogen Fuels using Nuclear Power", GA-A24285, Rev.1, General Atomics (2002).

5. O’Brien, J. E., Stoots, C. M., and Hawkes, G. L., "Comparison of a One-Dimensional Model of a High-Temperature Solid-OxideElectrolysis Stack with CFD and Experimental Results," 2005 ASME International Mechanical Engineering Congress and Exposition, Nov. 5 - 11, 2005, Orlando.

6. Stoots, C. M., O’Brien, J. E., McKellar, M. G., Hawkes, G. L., and Herring, J. S., "Engineering Process Model for High-Temperature Steam Electrolysis System Performance Evaluation," AIChE 2005 Annual Meeting, Cincinnati, Oct. 30 Nov. 4, 2005.

7. O'Brien, J. E., Stoots, C. M, Herring, J. S. , Hawkes, G. L., "Hydrogen Production From Nuclear Energy Via High Temperature Electrolysis," The $1^{\text {st }}$ Energy Center Hydrogen Initiative Symposium, Purdue University, West Lafayette, IN, April 5-6, 2006. 


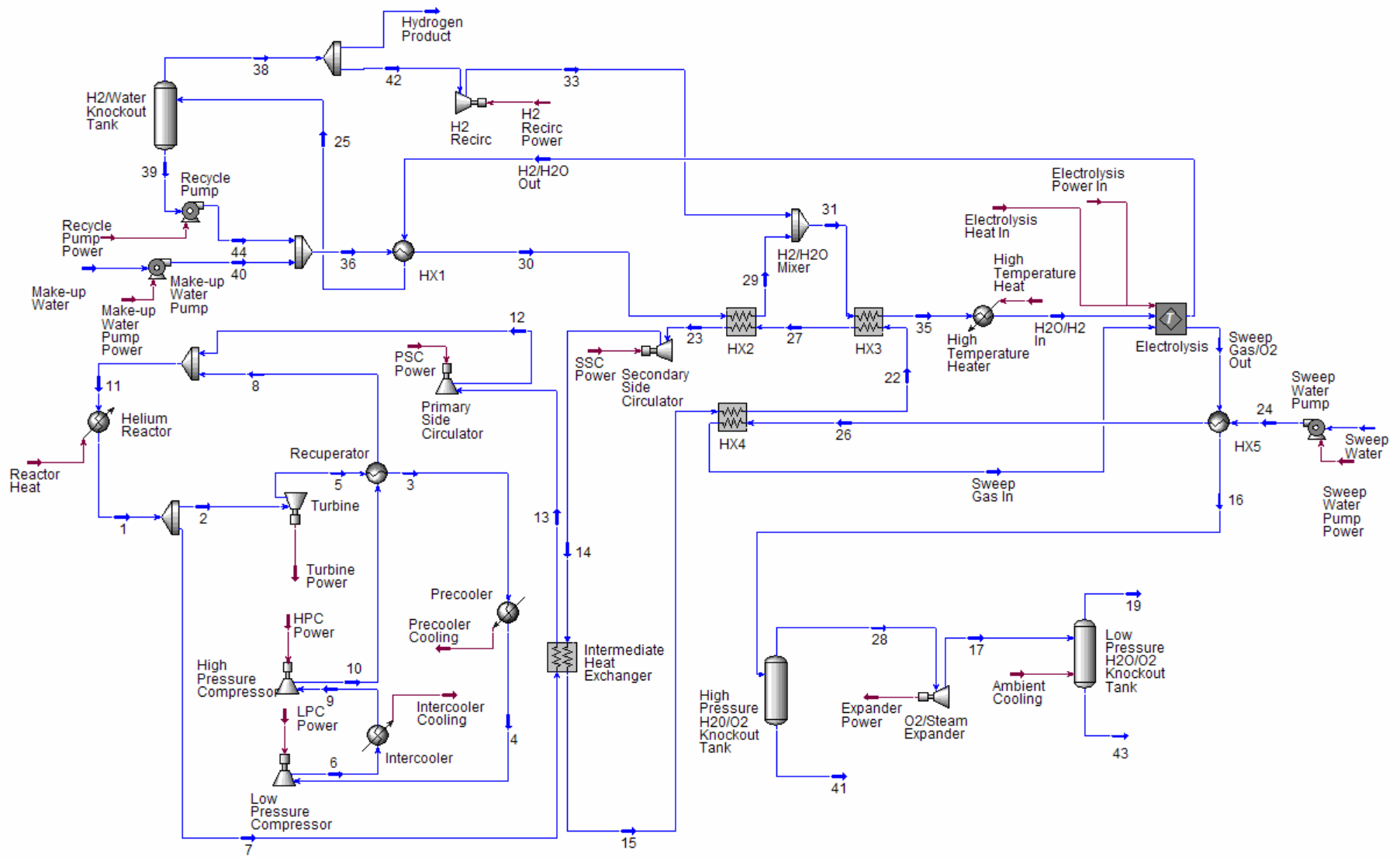

Figure 1. Process flow diagram of high temperature electrolysis process 


\begin{tabular}{|c|c|c|c|}
\hline Stream & Temperature $\left({ }^{\circ} \mathrm{C}\right)$ & Pressure $(\mathrm{MPa})$ & Flow $(\mathrm{kg} / \mathrm{s})$ \\
\hline Make-up Water & 21.1 & 0.101325 & 21.0 \\
\hline 40 - Make-up Water Pump Exit & 21.5 & 5.20 & 21.0 \\
\hline 44 - Water at Recycle Pump Exit & 27.2 & 5.20 & 2.60 \\
\hline 36 - Water Into HX1 & 22.2 & 5.20 & 23.6 \\
\hline $30-$ Steam/Water Out of HX1 & 267 & 5.15 & 23.6 \\
\hline 29 - Steam Out of HX2 & 281 & 5.10 & 23.6 \\
\hline 31 - Steam/Hydrogen Into HX3 & 258 & 5.10 & 23.9 \\
\hline 35 - Steam/Hydrogen Out of HX3 & 772 & 5.05 & 23.9 \\
\hline H2O/H2 In - Steam/Hydrogen Into Electrolysis & 827 & 5.00 & 23.9 \\
\hline $\mathrm{H} 2 / \mathrm{H} 2 \mathrm{O}$ Out - Steam/Hydrogen Out of Electrolysis & 862 & 5.00 & 5.26 \\
\hline 25 - Hydrogen/Water Out of HX1 & 27.2 & 4.95 & 5.26 \\
\hline 39 - Water at Recycle Pump Inlet & 27.2 & 4.95 & 2.60 \\
\hline 38 - Hydrogen at Vapor Outlet of H2/Water Knockout Tank & 27.2 & 4.95 & 2.66 \\
\hline Hydrogen Product & 27.2 & 4.95 & 2.36 \\
\hline 42 - Hydrogen into H2 Recirc & 27.2 & 4.95 & 0.295 \\
\hline 33 - Hydrogen Out of H2 Recirc & 30.7 & 5.10 & 0.295 \\
\hline Sweep Water - Water Into Sweep Water Pump & 21.1 & 0.101325 & 10.5 \\
\hline 24 - Water Out of Sweep Water Pump & 21.5 & 5.10 & 10.5 \\
\hline 26 - Steam Out of HX5 & 586 & 5.05 & 10.5 \\
\hline Sweep Gas In - Sweep Gas Into Electrolysis & 827 & 5.00 & 10.5 \\
\hline Sweep Gas/O2 Out - Steam/Oxygen Out of Electrolysis & 862 & 5.00 & 29.1 \\
\hline 16 - Steam/Water/Oxygen Out of HX5 & 202 & 4.95 & 29.1 \\
\hline 41 - Water Out of High Pressure H2O/O2 Knockout Tank & 202 & 4.95 & 4.45 \\
\hline 28 - Steam/Oxygen Into O2/Steam Expander & 202 & 4.95 & 24.6 \\
\hline 17 - Steam/Water/Oxygen After O2/Steam Expander & 67.0 & 0.101325 & 24.6 \\
\hline 19 - Oxygen Out of Low Pressure H2O/O2 Knockout Tank & 21.1 & 0.101325 & 18.9 \\
\hline 43 - Water Out of Low Pressure H2O/O2 Knockout Tank & 21.1 & 0.101325 & 5.78 \\
\hline
\end{tabular}

Table 5. Temperatures, pressures, and flow of electrolysis steam loop

\begin{tabular}{|l|c|}
\hline \multicolumn{1}{|c|}{ Component } & $\begin{array}{c}\text { Power or Heat Flow In } \\
(\mathrm{kW})\end{array}$ \\
\hline Make-up Pump Power & 141 \\
\hline Recycle Pump Power & 0.860 \\
\hline HX1 Duty & 43,425 \\
\hline HX2 Duty & 23,473 \\
\hline HX3 Duty & 30,440 \\
\hline High Temperature Heater Heat & 3,350 \\
\hline Electrolysis Power In & 291,989 \\
\hline H2 Recirc Power & 14.8 \\
\hline HX4 Duty & 5,971 \\
\hline HX5 Duty & 37,258 \\
\hline Sweep Water Pump Power & 69.1 \\
\hline O2/Steam Expander Power & 8,342 \\
\hline Ambient Cooling For Low & 10,503 \\
Pressure Knock Out Tank & \\
\hline
\end{tabular}

\begin{tabular}{|l|c|c|}
\hline Heat Exchanger & Effectiveness & $\begin{array}{c}\text { Minimum } \\
\text { Approach } \\
\text { Temperature } \\
\text { Difference }\left({ }^{\circ} \mathrm{C}\right)\end{array}$ \\
\hline Recuperator & 0.950 & 24.8 \\
\hline $\begin{array}{l}\text { Intermediate } \\
\text { Heat Exchanger }\end{array}$ & 0.950 & 32.9 \\
\hline HX1 & 0.793 & 5.0 \\
\hline HX2 & 0.950 & 13.2 \\
\hline HX3 & 0.863 & 81.6 \\
\hline HX4 & 0.727 & 90.3 \\
\hline HX5 & 0.841 & 5.0 \\
\hline
\end{tabular}

Table 7. Effectiveness of the heat exchangers in the process model

Table 6. Power and heat flow of electrolysis steam loop 


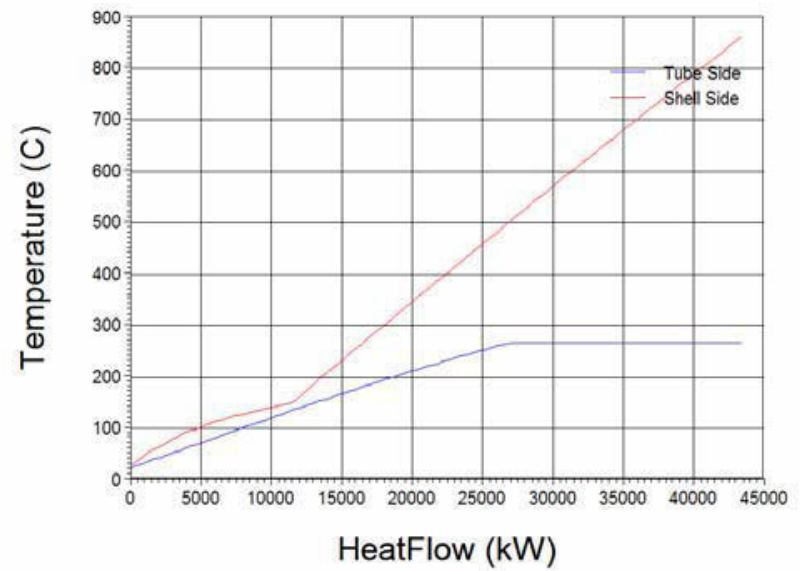

Figure 2. Temperature vs. Heat Flow Plot of HX1

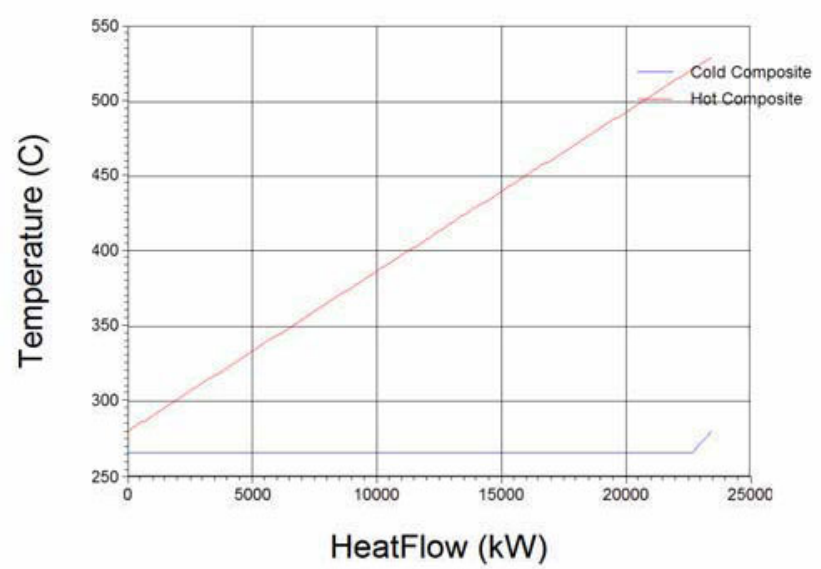

Figure 3. Temperature vs. Heat Flow Plot of HX2

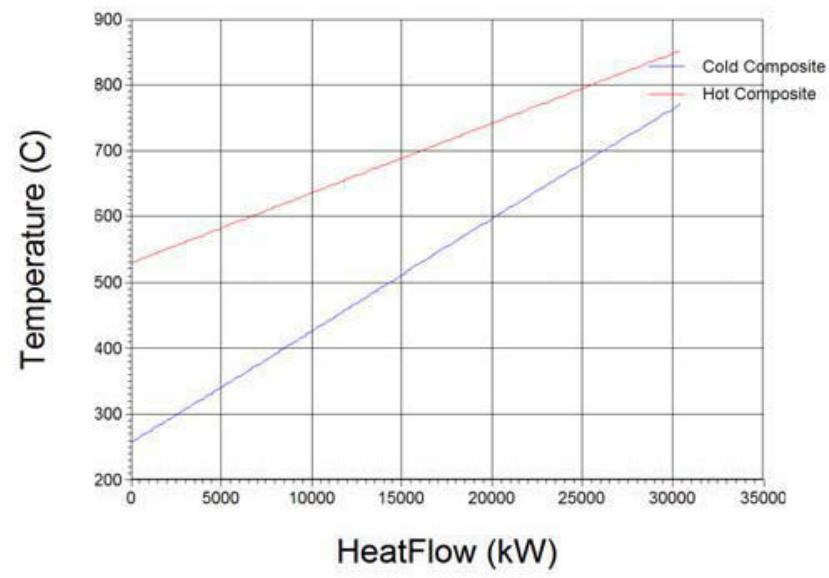

Figure 4. Temperature vs. Heat Flow Plot of HX3

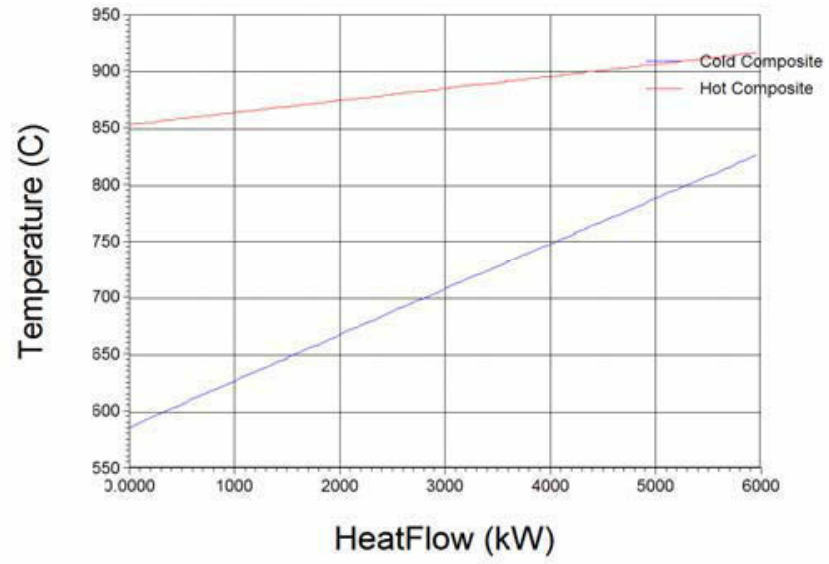

Figure 5. Temperature vs. Heat Flow Plot of HX4

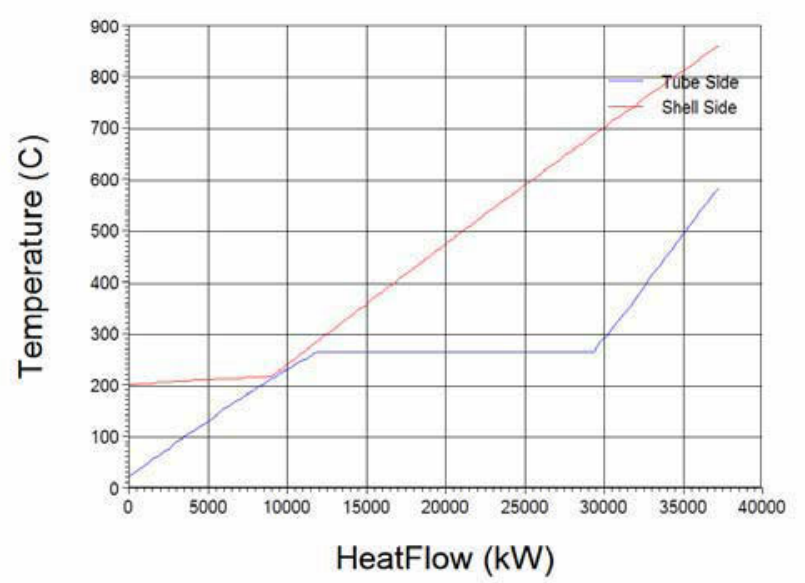

Figure 6. Temperature vs. Heat Flow Plot of HX5

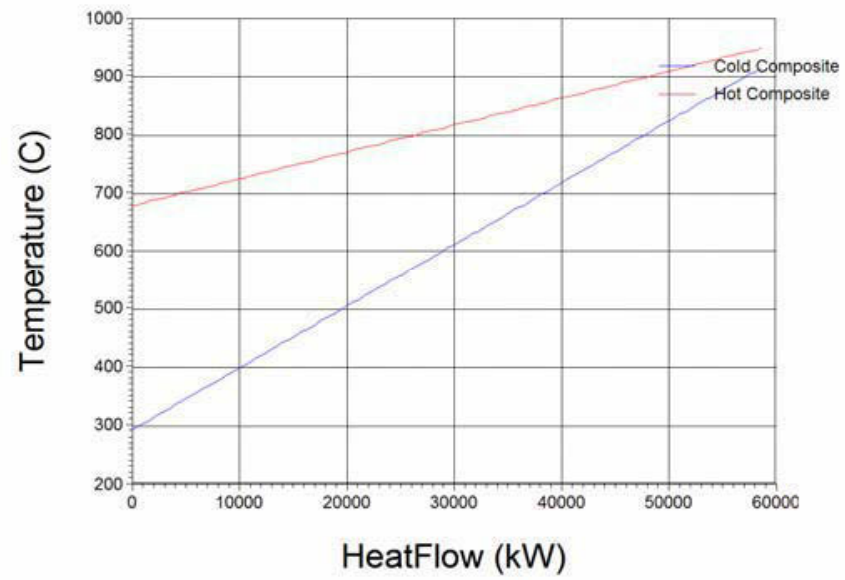

Figure 7. Temperature vs. Heat Flow Plot of Intermediate Heat Exchanger 